\title{
Comparison of fluticasone propionate and beclomethasone dipropionate on direct and indirect measurements of bronchial hyperresponsiveness in patients with stable asthma
}

\author{
G P Bootsma, P N R Dekhuijzen, J Festen, P G H Mulder, C L A van Herwaarden
}

\begin{abstract}
Background - Fluticasone propionate is a new inhaled corticosteroid with a $2: 1$ efficacy ratio compared with beclomethasone dipropionate with regard to lung function and symptom scores, without increased systemic activity. The aim of this study was to investigate whether this was also the case for bronchial hyperresponsiveness, assessed by both a direct (histamine) and an indirect (ultrasonically nebulised distilled water (UNDW)) provocation test.

Methods - Fluticasone propionate, $750 \mu \mathrm{g} /$ day, and beclomethasone dipropionate, $1500 \mu \mathrm{g} / \mathrm{day}$, were compared in a randomised, double blind, crossover study consisting of two six week treatment periods, each preceded by a three week single blind placebo period. Twenty one non-smoking asthmatics (mean forced expiratory volume in one second $\left(F_{E V}\right)$ $74.7 \%$ predicted, mean PC $_{20}$ histamine $0.36 \mathrm{mg} / \mathrm{ml}$ ) completed the study.
\end{abstract}

Results - Fluticasone propionate and beclomethasone dipropionate improved $F_{E V}$, peak flow rates, asthma symptoms, and bronchial hyperresponsiveness to the same extent. Both fluticasone propionate and beclomethasone dipropionate caused an increase in $\mathbf{P C}_{20}$ histamine (mean $2 \cdot 29$ [95\% confidence interval 1.45 to $3 \cdot 13$ ] and $1.95[1.07$ to $2 \cdot 84]$ doubling doses, respectively) and in PD $_{20}$ UNDW (1.12 [0.55 to $1 \cdot 70]$ and $1.28[0.88$ to $1 \cdot 70]$ doubling doses, respectively). Neither treatment changed morning serum cortisol levels, but fluticasone propionate decreased the number of peripheral blood eosinophils less than beclomethasone dipropionate, indicating smaller systemic effects of fluticasone propionate.

Conclusions - These findings show that fluticasone propionate is as effective as twice the dose of beclomethasone dipropionate on bronchial hyperresponsiveness, assessed by provocation with both histamine and UNDW, without increased systemic activity.

(Thorax 1995;50:1044-1050)

Keywords: bronchial hyperresponsiveness, fluticasone propionate, beclomethasone dipropionate.
Inhaled corticosteroids are currently the most effective anti-inflammatory drugs available for the treatment of asthma. ${ }^{1-3}$ Dosages above $1000 \mu \mathrm{g} /$ day may be necessary to control severe asthma, but these dosages are associated with systemic effects including a decrease in morning cortisol levels and adverse effects on parameters of bone turnover. ${ }^{3}$

Fluticasone propionate is a new inhaled corticosteroid with higher topical anti-inflammatory potency in humans than beclomethasone dipropionate and budesonide. ${ }^{4}$ Comparative studies indicate a 2:1 clinical potency ratio of fluticasone propionate compared with these inhaled steroids over a range of $200-1000 \mu \mathrm{g}$ fluticasone propionate daily. ${ }^{5-9}$ In these trials forced expiratory volume in one second $\left(\mathrm{FEV}_{1}\right)$, peak expiratory flow rate (PEFR), and symptom scores were used to evaluate clinical efficacy.

No comparisons have been made between fluticasone propionate and other inhaled steroids with regard to bronchial hyperresponsiveness, a major characteristic of asthma. Bronchial hyperresponsiveness can be measured by pharmacological (direct) stimuli such as histamine. Ultrasonically nebulised distilled water (UNDW), a physiological stimulus, induces airway narrowing indirectly and may better reflect the clinical severity of asthma. ${ }^{1011}$

The aim of this study was to compare the effects of inhaled fluticasone propionate ( $375 \mu \mathrm{g}$ twice daily) and inhaled beclomethasone dipropionate $(750 \mu \mathrm{g}$ twice daily) on bronchial hyperresponsiveness (assessed by provocation with histamine and UNDW), and on clinical efficacy in adult patients with stable asthma.

\section{Methods}

DESIGN AND TREATMENT

The study was a randomised, crossover trial, with a three week single blind washout (placebo) period before each of the two six week double blind active treatment periods. A schematic overview is shown in fig. 1. Currently used inhaled corticosteroids were discontinued at the start of the first placebo (washout) period. Measurements made at the end of the two placebo (washout) periods were regarded as baseline values before the active treatment periods. After the first placebo (run in) period 


$\begin{array}{cc}\text { Placebo } & \text { Placebo } \\ \text { wash-out } \\ \text { (run-in) } & \text { wash-out }\end{array}$
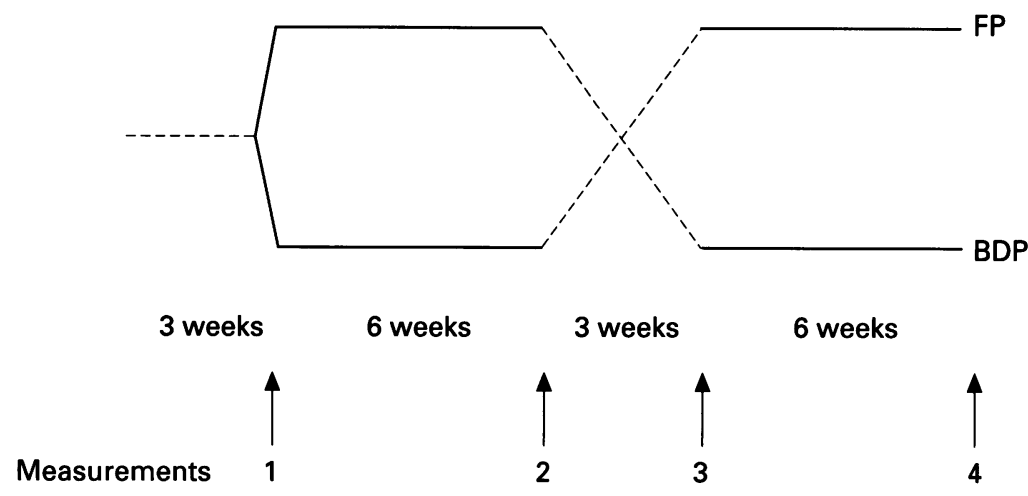

Figure 1 Design of the study. $F P=$ fluticasone propionate $750 \mu \mathrm{g}$ daily; $B D P=$ beclomethasone dipropionate $1500 \mu \mathrm{g}$ daily.

a final evaluation was made to check if the patient met all inclusion criteria. If so, they randomly received fluticasone propionate $750 \mu \mathrm{g}$ daily or beclomethasone dipropionate $1500 \mu \mathrm{g}$ daily for six weeks.

Throughout the study the patients took three inhalations of the study medication twice daily. The inhalations were taken from a metered dose inhaler containing either placebo, fluticasone propionate $125 \mu \mathrm{g}$, or beclomethasone dipropionate $250 \mu \mathrm{g}$ per dose. The patients used a salbutamol metered dose inhaler $(100 \mu \mathrm{g})$ as required as rescue medication. Patients were instructed on the correct usage of their inhaler. No other pulmonary medication was allowed.

\section{SUBJECTS}

Thirty adult non-smoking patients with asthma according to the criteria of the American Thoracic Society ${ }^{12}$ were recruited from the outpatient department. Baseline characteristics of these subjects are shown in table 1 . All but one used inhaled corticosteroids before entering the study, with a mean (SE) daily dose of 790 (54) $\mu \mathrm{g}$. At the start of the first placebo (washout and run in) period patients discontinued their inhaled steroids. Allergy was defined as raised specific IgE levels or positive skin tests for housedust mite or two of seven other common aeroallergens tested. ${ }^{13}$ To be included in the study patients needed to be symptomatic, defined as having $\geqslant 4$ symptom days during the last week, or $\geqslant 7$ symptom days during the last two weeks of the first placebo (run in) period. Days were considered as symptom days when patients recorded at least one asthma symptom on the record cards (see below) during that day. At the end of the run in period, $\mathrm{FEV}_{1}$ had to be $\geqslant 50 \%$ of predicted and patients needed to have a provocative concentration of histamine causing a $20 \%$ fall in $\mathrm{FEV}_{1} \quad\left(\mathrm{PC}_{20}\right.$ histamine) below $4 \mathrm{mg} / \mathrm{ml}$, indicating overt bronchial hyperresponsiveness. ${ }^{14}$ Subjects with seasonal allergy did not participate in the study during that specific season. None of the patients had used systemic corticosteroids in the six months preceding the study. Patients with an upper or lower res- piratory tract infection within six weeks before the start of the study were excluded. The study was approved by the Nijmegen University medical ethics committee. All subjects gave written informed consent.

\section{BRONCHIAL HYPERRESPONSIVENESS AND LUNG} FUNCTION

At the end of the four periods a histamine and a UNDW provocation test were performed at the same time on two different days in order to avoid tachyphylaxis for the different tests. ${ }^{15}$ Subjects did not use rescue or study medication for at least eight hours before each visit, and rested 15 minutes before the measurements were started.

Lung function and responses to provocation with histamine ( $\mathrm{PC}_{20}$ histamine) and UNDW $\left(\mathrm{PD}_{20} \mathrm{UNDW}\right.$ ) were assessed by $\mathrm{FEV}_{1}$, measured with a flow-volume curve recorded on a heated pneumotachograph (Spiro analyser ST 250; Fukuda Sangyo Co, Tokyo, Japan). Baseline lung function was recorded as the best of three reproducible values of $\mathrm{FEV}_{1}$ (within 5\%) before the provocation tests.

The histamine provocation test was carried out according to the method of Cockcroft et al. ${ }^{14}$ For two minutes patients inhaled doubling concentrations of histamine acid phosphate by tidal breathing, increasing from 0.03 to $16 \mathrm{mg} /$ ml. Histamine was nebulised with a DeVilbiss 646 nebuliser (DeVilbiss, Somerset, Pennsylvania, USA) with a fixed output of $0.13 \mathrm{ml} /$ min. $\mathrm{PC}_{20}$ histamine was determined in $\mathrm{mg} / \mathrm{ml}$ by interpolating the last two points of the doseresponse curve on a semilogarithmic scale.

The UNDW provocation test was performed according to the method of Groot et al. ${ }^{15}$ UNDW was generated with an ultrasonic nebuliser (Ultraneb 99, DeVilbiss, Somerset, Pennsylvania, USA) at a fixed output of 2.00 $(0.05) \mathrm{ml} / \mathrm{min}$. After inhalation of 20 litres of ambient air through the system, patients inhaled doubling volumes of air with UNDW (3, 5,10 , up to 160 litres), measured with a Wright respirometer (British Oxygen Co, London, UK). The respirometer was placed between the aerosol hose and the mouthpiece by means of a two way valve. Before and after each test the nebuliser chamber and aerosol hose were weighed to determine the exact amount of distilled water inhaled. The cumulative amount of inhaled water $\left(\mathrm{ml} \mathrm{H}_{2} \mathrm{O}\right)$ causing a $20 \%$ fall in $\mathrm{FEV}_{1}$ from post-air values ( $\mathrm{PD}_{20} \mathrm{UNDW}$ ) was calculated by linear interpolation on a semilogarithmic curve.

\section{DAILY RECORD CARDS}

During the last three weeks of each of the four periods, patients recorded PEFR, use of study and rescue inhaler, asthma symptoms, and adverse events every day. The best of three PEFR measurements with a mini-Wright peak flow meter was recorded every morning and evening, before medication. The severity of dyspnoea during the day, during the night, and during exercise was registered on a visual analogue scale ranging from 0 to $100 \mathrm{~mm} .^{16}$ 


\section{LABORATORY EVALUATION}

At the end of the four treatment periods a peripheral blood sample was taken between 0700 and 0900 hours (individual patients always at the same time) for measurement of total numbers of eosinophils and cortisol.

Total numbers of eosinophils were measured with a Technicon $\mathrm{H} 1$ analyser (Technicon Instrument Co, Tarrytown, New York, USA). Cortisol levels were immediately determined using an in-house radioimmunoassay involving heat inactivation of corticosteroid binding globulin. The lower limit of normal for morning serum cortisol levels in our laboratory is $0 \cdot 19 \mu \mathrm{mol} / 1$.

\section{STATISTICAL ANALYSIS}

Treatments were randomly allocated to five groups of six patients each according to the PACT computer programme. Each consecutive patient was allocated the next randomisation number after meeting the entry criteria at visit 1 .

Four repeated measurements were made, at the start and at the end of each of both treatment periods (measurements $1-4$, fig 1 ). The carryover effect of the first treatment at the start of the second treatment period (measurement 3 ) is a first order carryover effect, which may still be partly present at the end of the second treatment period (measurement 4). This latter part is the second order carryover effect which may interfere with the treatment effect. The first order carryover effect was tested by comparing the differences of measurements 3 and 1 between the two randomised treatment groups. Theoretically, the second order carryover effect is tested by comparing the sum of measurements 2 and 4 between the treatment order groups. ${ }^{17}$ However, in the present study some imbalance was present in several outcome variables between the two treatment groups at the start of the study, despite randomisation. In order to correct for this imbalance present at measurement 1 , the second order carryover effect was tested by comparing the sum of two differences - that is, 2 minus 1 and 4 minus 1 - between the two treatment groups. Provided that there was no second order carryover effect, the treatment effect was tested next by comparing the difference of measurements 2 and 4 between the treatment order groups. The treatment effect "fluticasone propionate (FP) minus beclomethasone dipropionate (BDP)" was estimated by taking half the difference between the two treatment order groups of the within group mean differences of measurements 2 and

Table 1 Mean (SD) baseline characteristics of the patients

\begin{tabular}{lll}
\hline & $\begin{array}{l}\text { At start of study } \\
(n=30)\end{array}$ & $\begin{array}{l}\text { After first placebo } \\
\text { (run in) period }(n=21)\end{array}$ \\
\hline Sex (M/F) & $14 / 16$ & $10 / 11$ \\
Age (years) & $30 \cdot 3(7 \cdot 4)$ & $30 \cdot 2(8 \cdot 1)$ \\
Allergy (positive) & 25 & 18 \\
FEV 1 (\% pred) & $84 \cdot 8(18 \cdot 8)$ & $74 \cdot 7(18 \cdot 1)$ \\
$\log _{2} \mathrm{PC}_{20}$ histamine $(\mathrm{mg} / \mathrm{ml})$ & & $-2 \cdot 85(1 \cdot 98)$ \\
$\log _{2} \mathrm{PD}_{20} \mathrm{UNDW}(\mathrm{ml} \mathrm{H} \mathrm{O})$ & & $0 \cdot 92(1 \cdot 73)$ \\
\hline
\end{tabular}

$\mathrm{PC}_{20}$ histamine $=$ provocative concentration of histamine causing a $20 \%$ fall in $\mathrm{FEV}_{1}$ $\mathrm{PD}_{20} \mathrm{UNDW}=$ provocative dose of ultrasonically nebulised distilled water causing a $20 \%$ fall in $\mathrm{FEV}_{1}$.
4: $((\mathrm{FP}-\mathrm{BDP})-(\mathrm{BDP}-\mathrm{FP})) / 2 .{ }^{17}$ Alternatively, the clinical efficacy of each treatment was also expressed by taking the differences between the measurements at the end of either treatment period and the associated baseline measurement at the start of the treatment period considered.

All $\mathrm{PC}_{20}$ histamine and $\mathrm{PD}_{20} \mathrm{UNDW}$ data were $\log _{2}$ transformed before analysis, hence changes in $\mathrm{PC}_{20}$ histamine and $\mathrm{PD}_{20} \mathrm{UNDW}$ were expressed as doubling doses of inhaled histamine and UNDW. The standard deviation of the differences between two repeated measurements (SD-rm) for these provocation tests was calculated between the two baseline values. ${ }^{18}$ From the parameters recorded on the diary card (PEFR, symptom scores, additional use of bronchodilator) the mean of all values recorded during the last two weeks of each period was used for statistical analysis. PEFR variability was defined as the difference between morning and evening reading (highest minus lowest value), expressed as a percentage of the mean of both readings. ${ }^{19}$ The Wilcoxon signed rank test or the paired $t$ test were used for analysis when appropriate. Correlations were calculated by means of the Spearman rank correlation coefficient, $p$ values of $<0.05$ being considered significant. Data are reported as mean (SE) values unless specified otherwise.

\section{Results}

Thirty patients entered the first placebo (run in) period. Two patients did not meet the final criteria after the run in period because they
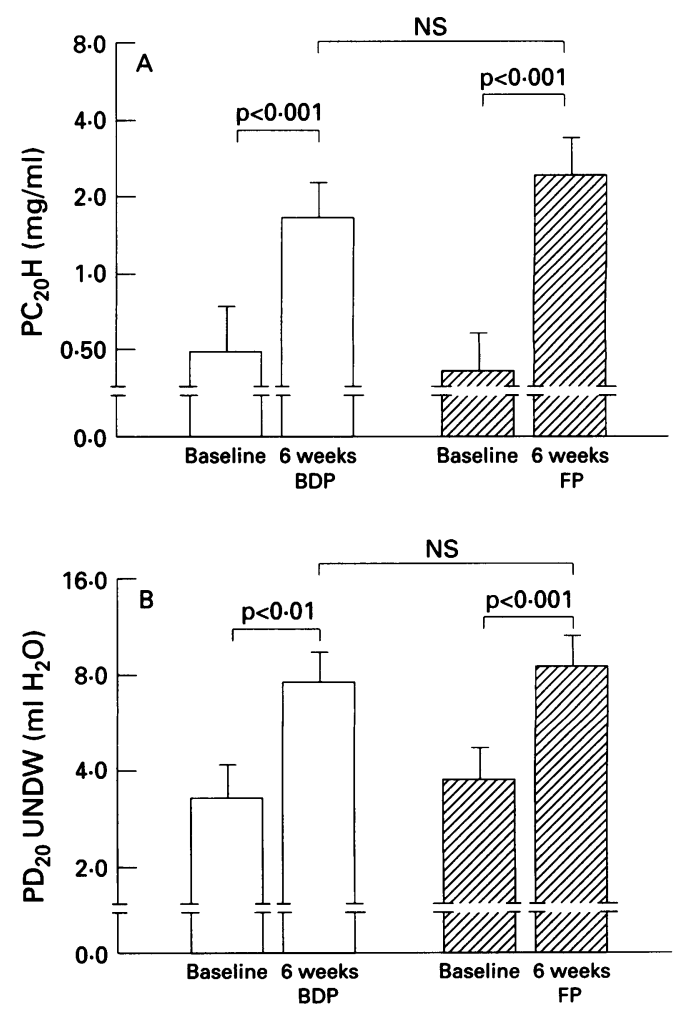

Figure 2 Mean (SE) values of (A) $P C_{20} H$ (provocative concentration of histamine causing a $20 \%$ fall in $F E V$ ) and $(B) P D_{20} U N D W$ (provocative dose of ultrasonically nebulised distilled water causing a $20 \%$ fall in $F E V$ ) . $\square$, beclomethasone dipropionate (BDP); $\mathbb{Z}$, fluticasone propionate (FP). 
experienced no asthma symptoms during that period. Seven patients dropped out in the run in period because of an exacerbation of their asthma after withdrawal of their inhaled corti-
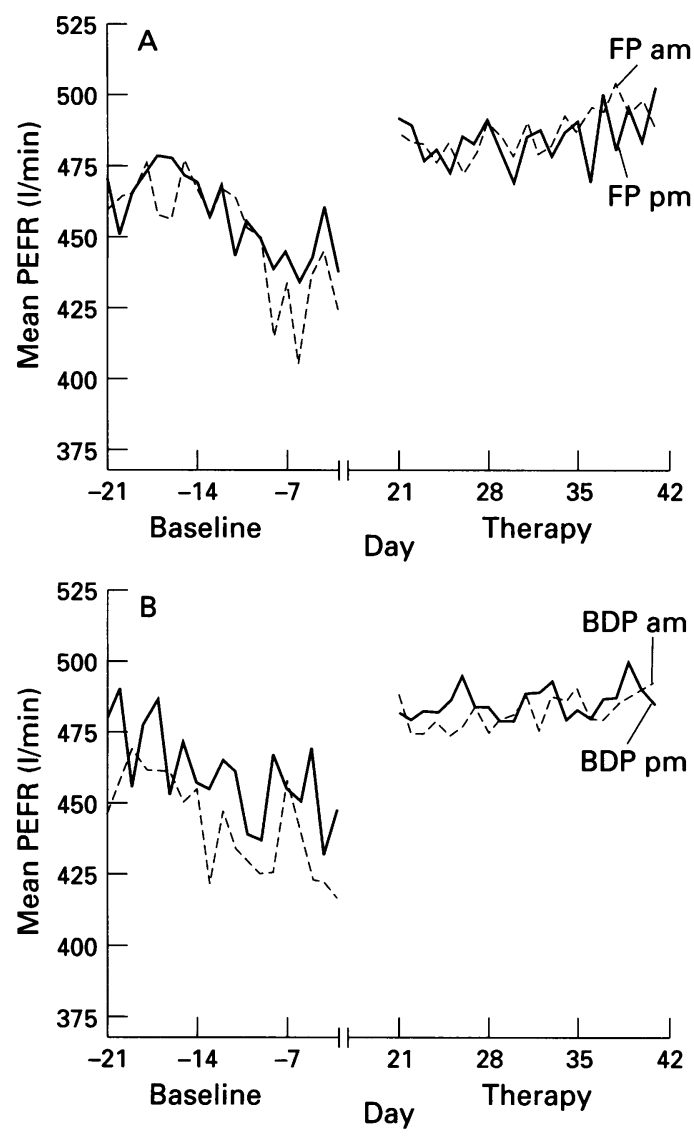

Figure 3 Morning (am) (--) and evening (pm) (-) peak expiratory flow rates (PEFR) during the three week placebo (washout) period and after 3-6 weeks of treatment with (A) fluticasone propionate (FP) $750 \mu \mathrm{g} /$ day and (B) beclomethasone dipropionate (BDP) $1500 \mu \mathrm{g} /$ day.

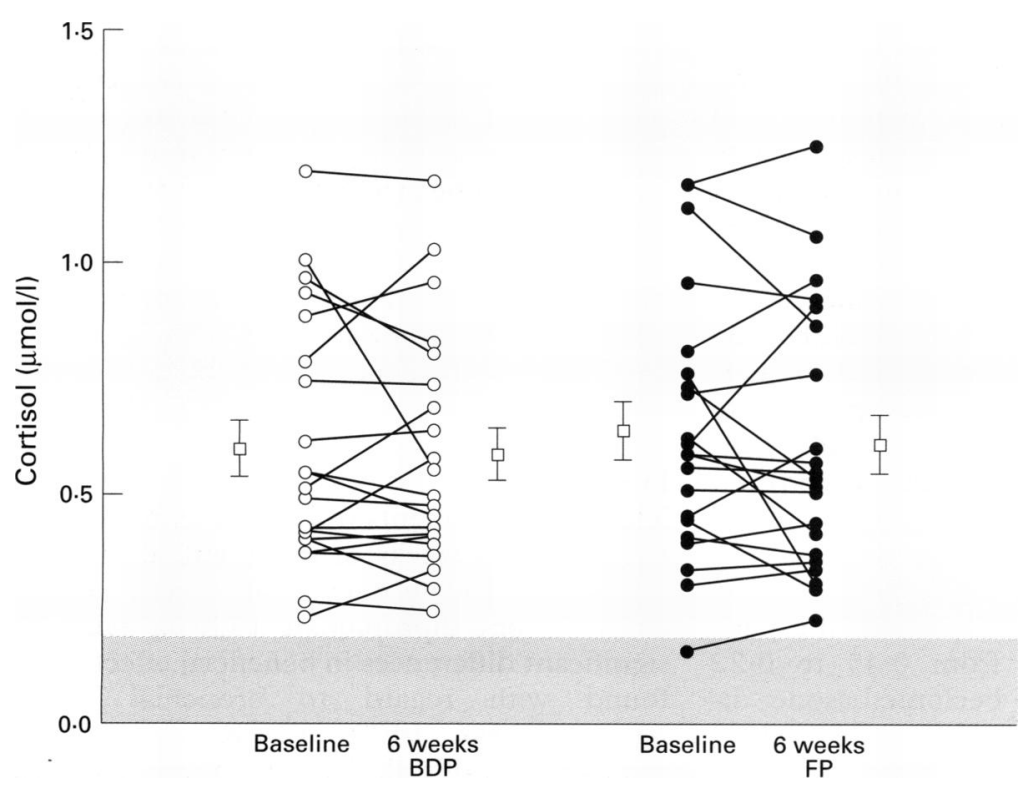

Figure 4 Change in individual morning serum cortisol values from baseline to six weeks after treatment and mean ( $\square$ ) (SE) values with fluticasone propionate (FP) $750 \mu$ g/day (O) and beclomethasone dipropionate $(B D P) 1500 \mu g / d a y(O)$. The lower limit of normal $(0.19 \mu \mathrm{mol} / \mathrm{l})$ is indicated at the bottom of the figure. costeroid. The remaining 21 patients all completed the study. Of these patients, 14 started with beclomethasone dipropionate and seven with fluticasone propionate. Since patients actually dropped out on the basis of prerandomisation criteria, this did not affect the validity of the study.

There were no first and second order carryover effects for any variable measured. The treatment effects of fluticasone propionate and beclomethasone dipropionate were therefore compared by analysing the difference of measurements 2 and 4 between the treatment order groups (table 2). Furthermore, the clinical efficacy of both inhaled steroids was analysed by comparing the treatment effects with their own baseline value (table 2 ) ( $\Delta$ effects). No significant differences were found in any variable at the end of each placebo period.

\section{BRONCHIAL HYPERRESPONSIVENESS AND LUNG} FUNCTION

Both fluticasone propionate and beclomethasone dipropionate caused a significant decrease in bronchial hyperresponsiveness. On average, $\mathrm{PC}_{20}$ histamine increased by $2.29[95 \%$ confidence interval (CI) 1.45 to $3 \cdot 13$ ] and by 1.95 [ 1.07 to $2 \cdot 84]$ doubling doses, respectively (both $\mathrm{p}<0.001$ ). PD $_{20}$ UNDW increased by $1 \cdot 12[0.55$ to $1 \cdot 70]$ and by $1.28[0.88$ to $1 \cdot 70]$ doubling doses, respectively $(\mathrm{p}<0.001$ and $\mathrm{p}<0.005$, respectively) (fig 2 ). The SD-rm of the two baseline measurements was 0.33 doubling doses for the histamine provocation test and 0.23 doubling doses for the UNDW provocation test.

$\mathrm{PC}_{20}$ histamine and $\mathrm{PD}_{20} \mathrm{UNDW}$ were significantly correlated both after placebo $(\rho=$ $0.74 ; \mathrm{p}<0.001$ ) and after treatment with fluticasone propionate $(\rho=0.54 ; p<0.05)$ and beclomethasone dipropionate $(\rho=0.51 ; p<0.05)$. There were no significant differences between the effects of fluticasone propionate and beclomethasone dipropionate on bronchial hyperresponsiveness and $\mathrm{FEV}_{1}$ (table 2). $\mathrm{FEV}_{1}$ increased by $0.45(0.12) 1$ after fluticasone propionate (from $74 \cdot 1 \%$ to $86.9 \%$ predicted; $\mathrm{p}<0.005)$, and by $0.34(0.09) 1$ after beclomethasone dipropionate (from $76 \cdot 4 \%$ to $85 \cdot 8 \%$ predicted; $\mathrm{p}<0.001$ ).

\section{DAILY RECORD CARDS}

Compared with baseline values, PEFR showed increases in morning and evening values after both fluticasone propionate and beclomethasone dipropionate (all $\mathrm{p}<0.01$ ). The diurnal variation in PEFR decreased significantly after fluticasone propionate but not after beclomethasone dipropionate (table 2, fig 3 ). The treatment effects of fluticasone propionate and beclomethasone dipropionate were not significantly different (table 2 ).

The use of $\beta_{2}$ agonists decreased significantly compared with baseline, both with fluticasone propionate and beclomethasone dipropionate, the treatment effect not being different with either steroid (table 2). Dyspnoea scores, recorded on a visual analogue scale, decreased 
Table 2 Clinical efficacy and mutual comparison of fluticasone propionate (FP) and beclomethasone dipropionate $(B D P)$

\begin{tabular}{|c|c|c|c|c|}
\hline \multirow[t]{2}{*}{ Parameter } & \multirow[t]{2}{*}{$\begin{array}{l}\text { Baseline } \\
\text { (mean (SE)) }\end{array}$} & \multirow{2}{*}{$\begin{array}{l}\text { After } 6 \text { weeks } \\
\text { treatmentt } \\
\text { (mean (SE)) }\end{array}$} & \multicolumn{2}{|c|}{$\begin{array}{l}\text { Difference in treatment effect } \neq \\
F P-B D P\end{array}$} \\
\hline & & & Mean (SE) & $95 \% C I$ \\
\hline $\begin{array}{l}\text { PC }_{20} \text { histamine }(\mathrm{mg} / \mathrm{ml}) \\
\text { FP }\end{array}$ & $0.41(0.17)$ & $2 \cdot 42(0 \cdot 17)^{* * *}$ & \multirow[b]{2}{*}{$0.55(0.3) \mathrm{DD}$} & \multirow[b]{2}{*}{-0.10 to 1.21} \\
\hline $\begin{array}{l}\text { BDP } \\
\text { PD }_{20} \mathrm{UNDW}\left(\mathrm{ml} \mathrm{H}_{2} \mathrm{O}\right)\end{array}$ & $0.49(0.24)$ & $1.63(0.61)^{* * *}$ & & \\
\hline FP & $3.77(1.00)$ & $8.62(1.93)^{* * *}$ & $0.03(0.3) \mathrm{DD}$ & -0.63 to 0.65 \\
\hline $\begin{array}{l}\text { BDP } \\
\mathrm{FEV}_{1}(\mathbf{l}) \\
\mathrm{FP}\end{array}$ & $\begin{array}{l}3.29(0.91) \\
2.83(0.18)\end{array}$ & $\begin{array}{l}7.63(1.78)^{* *} \\
3.28(0.13)^{* *}\end{array}$ & & \\
\hline $\begin{array}{l}\text { BDP } \\
\text { PEFR morning (1/min) }\end{array}$ & $2 \cdot 90(0 \cdot 15)$ & $3 \cdot 24(0 \cdot 14)^{* *}$ & $0.06(0.07)$ & -0.08 to 0.21 \\
\hline FP & $438 \cdot 4(21 \cdot 2)$ & $489 \cdot 9(17 \cdot 3)^{* * *}$ & \multirow{2}{*}{$5.57(5.5)$} & \multirow{2}{*}{$6 \cdot 31$ to $17 \cdot 5$} \\
\hline $\begin{array}{l}\text { BDP } \\
\text { PEFR evening }(1 / \mathrm{min})\end{array}$ & $433.6(20 \cdot 8)$ & $479.9(17 \cdot 7)^{* * *}$ & & \\
\hline FP & $448 \cdot 1(17 \cdot 2)$ & $487 \cdot 9(15 \cdot 8)^{* * *}$ & \multirow{2}{*}{$2.69(6.5)$} & \multirow{2}{*}{-10.9 to $16 \cdot 3$} \\
\hline $\begin{array}{l}\text { BDP } \\
\text { Diurnal variation }(\%) S\end{array}$ & $445 \cdot 3(16 \cdot 3)$ & $474 \cdot 5(15 \cdot 0)^{* *}$ & & \\
\hline FP & $6.89(0.90)$ & $3.97(0.50)^{* *}$ & \multirow{2}{*}{$-0.59(0.64)$} & \multirow{2}{*}{-1.93 to 0.76} \\
\hline $\begin{array}{l}\text { BDP } \\
\beta_{2} \text { agonist use (puffs/day) }\end{array}$ & $8.70(1.92)$ & $5.11(0.59)$ & & \\
\hline & $2.23(0.35)$ & $1.03(0.29)^{* * *}$ & \multirow{2}{*}{$-0.25(0.22)$} & \multirow{2}{*}{-0.72 to 0.21} \\
\hline BDP & $2.36(0.43)$ & $1.40(0.34)^{* *}$ & & \\
\hline
\end{tabular}

$\dagger \Delta$ treatment effects are calculated as treatment values versus corresponding baseline values. NS $=$ not significant; ${ }^{* *} \mathrm{p}<0 \cdot 01$; $* * * \mathrm{p}<0.001$.

₹ Treatment effects of FP and BDP are directly compared by analysing the difference of their treatment effects between treatment order groups $((\mathrm{FP}-\mathrm{BDP})-(\mathrm{BDP}-\mathrm{FP})) / 2$.

$\S$ Difference between morning and evening reading expressed as percenatage of the mean of both readings.

during daytime from $18 \cdot 1(2 \cdot 7)$ to $7 \cdot 3(2 \cdot 1)$ $\mathrm{mm}$ after fluticasone propionate and from $14 \cdot 8$ $(3 \cdot 0)$ to $6 \cdot 4(1.9) \mathrm{mm}$ after beclomethasone dipropionate (both $\mathrm{p}<0.001$ ). Night time dyspnoea scores decreased from 17.1 (2.9) to $5 \cdot 6$ $(2.0) \mathrm{mm}$ after fluticasone propionate and from $14.9(3.6)$ to $5.9(2.2) \mathrm{mm}$ after beclomethasone dipropionate (both $\mathrm{p}<0.001$ ). There were no significant treatment effects between fluticasone propionate and beclomethasone dipropionate.

No serious adverse events were reported during the study. During treatment with both fluticasone propionate and with beclomethasone dipropionate three subjects reported a sore throat not related to a common cold. Other adverse events, unlikely to be related to the use of the study drugs, included common cold (seven times with fluticasone propionate, four times with beclomethasone dipropionate, and six times with placebo), nausea and stomach ache (twice with beclomethasone dipropionate), headache (once with fluticasone propionate, three times with beclomethasone dipropionate and five times with placebo), diarrhoea (once both with fluticasone propionate and beclomethasone dipropionate), and generalised itching (three times with placebo).

\section{LABORATORY EVALUATION}

The total number of eosinophils in the peripheral blood decreased from 0.45 to 0.22 $\times 10^{9} / 1 \quad(p<0.001)$ after beclomethasone dipropionate, and from 0.41 to $0.30 \times 10^{9} / 1$ $(p<0.001)$ after fluticasone propionate. This treatment effect was significantly different, with a mean difference between fluticasone propionate and beclomethasone dipropionate of $0.076 \times 10^{9} / 1(95 \%$ CI 0.024 to 0.13$)$.
Neither fluticasone propionate nor beclomethasone dipropionate affected morning cortisol levels significantly, as shown in fig 4. The seven patients with high values of morning cortisol $(>0.70 \mu \mathrm{mol} / \mathrm{l})$ were all women, six of whom were taking oral contraceptive drugs. Oestrogens in oral contraceptive drugs are known to increase the production of corticosteroid binding globulin, which probably accounts for the high values of cortisol in these patients. ${ }^{20}$ The only patient with a large decrease $(0.45 \mu \mathrm{mol} / 1)$ in morning cortisol levels after treatment with beclomethasone dipropionate also showed a substantial decrease $(0.25 \mu \mathrm{mol} / \mathrm{l})$ after treatment with fluticasone propionate. In no patient did the cortisol level fall below the lower limit of normal after treatment. Mean cortisol values did not change significantly (from baseline 0.64 to $0.61 \mu \mathrm{mol} /$ 1 after fluticasone propionate, and from baseline 0.60 to $0.59 \mu \mathrm{mol} / 1$ after beclomethasone dipropionate). There was no difference in treatment effect between fluticasone propionate and beclomethasone dipropionate.

\section{Discussion}

This study in patients with stable asthma shows that, after six weeks of treatment, fluticasone propionate $750 \mu \mathrm{g}$ daily is as effective as beclomethasone dipropionate $1500 \mu \mathrm{g}$ daily. No significant differences in beneficial effects were found with regard to bronchial hyperresponsiveness, FEV $_{1}$, PEFR, and asthma symptoms. Both fluticasone propionate and beclomethasone dipropionate caused a significant decrease in bronchial hyperresponsiveness, assessed by both the histamine and the UNDW provocation test. Neither 
steroid significantly changed morning cortisol levels.

This is the first study to test the hypothesis that fluticasone propionate may provide an equal effect on bronchial hyperresponsiveness, a major characteristic of asthma, at half the microgram dose of beclomethasone dipropionate. Until now all comparative studies in mild, moderate, and severe asthmatics have shown a 2:1 ratio in clinical effects. This was shown over a wide dose range, from 200 to $1000 \mu \mathrm{g}$ fluticasone propionate $(400-2000 \mu \mathrm{g}$ beclomethasone dipropionate, ${ }^{5-7}$ and $400 \mu \mathrm{g}$ budesonide $^{8}$ ). Furthermore, in an open study $400 \mu \mathrm{g}$ fluticasone propionate was more effective than $800 \mu \mathrm{g}$ budesonide, ${ }^{9}$ and both 1000 and $2000 \mu \mathrm{g}$ fluticasone propionate were significantly more effective than $1600 \mu \mathrm{g}$ budesonide. ${ }^{21}$ Fabbri et $a l^{2}$ compared fluticasone propionate and beclomethasone dipropionate in an equal dose $(1500 \mu \mathrm{g}$ daily $)$ in patients with moderate to severe asthma. Fluticasone propionate caused a significantly greater increase in asthma control than beclomethasone dipropionate. The present study confirms a similar ratio with regard to lung function, PEFR, symptom scores, and use of $\beta_{2}$ agonists as that shown in previous comparative trials. ${ }^{4-9}$ On all parameters fluticasone propionate was as effective as twice the dose of beclomethasone dipropionate (table 2).

The extent to which fluticasone propionate and beclomethasone dipropionate reduced bronchial hyperresponsiveness is in line with that in previous studies. In mild asthmatics fluticasone propionate $1000 \mu \mathrm{g}$ daily for two weeks improved $\mathrm{PC}_{20}$ histamine by 1.3 doubling doses. ${ }^{23}$ The average increase in PC $_{20}$ histamine or methacholine after chronic treatment with beclomethasone dipropionate or budesonide, as recently reviewed by Barnes et al, ${ }^{3}$ is also of the order of one or two doubling doses. The extent of the response depends on dose, duration of treatment, and degree of steroid responsiveness. Treatment with a similar dose of budesonide $(1600 \mu \mathrm{g}$ daily) during six weeks improved $\mathrm{PD}_{20}$ histamine by 2.4 doubling doses $^{24}$ compared with $2 \cdot 3$ doubling doses for fluticasone propionate and $2 \cdot 0$ doubling doses for beclomethasone dipropionate in this study. The extent of the increase in $\mathrm{PD}_{20} \mathrm{UNDW}(1 \cdot 1$ and 1.3 doubling doses) is slightly less than in the study of Groot et a ${ }^{25}$ ( 1.8 doubling doses after four weeks of beclomethasone dipropionate $800 \mu \mathrm{g}$ daily). This may be explained by the fact that at baseline our patients were less responsive to UNDW, the $\mathrm{PD}_{20}$ UNDW being 3.3 and $3.8 \mathrm{ml} \mathrm{H}_{2} \mathrm{O}$, compared with $1.3 \mathrm{ml} \mathrm{H}_{2} \mathrm{O}$ in the study by Groot et $\mathrm{al}^{25}$

To assess efficacy of treatment an indirect challenge, as with UNDW, may be preferable because it mimicks naturally occurring bronchoconstrictor stimuli and because it reflects the severity of asthma better. ${ }^{111}$ Inhaled histamine acts mainly directly on the airway smooth muscle. ${ }^{10}$ In contrast, UNDW induces bronchoconstriction by cell-mediated events. ${ }^{11}$ Challenge with UNDW may increase bronchial hyperresponsiveness and induce a late asth- matic response, just as exposure to allergens. ${ }^{26}$ It has been suggested that inhaled corticosteroids may have a greater effect on indirect than on direct challenges, because they not only affect smooth muscle responsiveness but also reduce the airway mast cell function. ${ }^{27}$ This concept could not be confirmed in the present study because both fluticasone propionate and beclomethasone dipropionate caused a strong decrease in bronchial hyperresponsiveness in both tests. Compared with the SD-rm of the challenges, both steroids improved the $\mathrm{PC}_{20}$ histamine about sixfold, and the $\mathrm{PD}_{20} \mathrm{UNDW}$ about fivefold, indicating equal effects on both parameters. Similarly, the study of Groot et $a l^{25}$ showed no advantage of UNDW over histamine. Nevertheless, the low correlation coefficient between $\mathrm{PC}_{20}$ histamine and $\mathrm{PD}_{20} \mathrm{UNDW}$ after treatment indicates that both challenges test different aspects of bronchial hyperresponsiveness.

A potential drawback of our study was the crossover design, because it may take several weeks before bronchial hyperresponsiveness returns to baseline values after discontinuation of inhaled steroids. ${ }^{28}$ However, after the second washout period (measurement 3) all parameters, including bronchial hyperresponsiveness, returned to pretreatment levels (measurement 1). Therefore, carryover effects are not likely to have affected the outcome in the present study both from a statistical point of view and in terms of clinical relevance.

Fluticasone propionate may offer some advantages over previous inhaled steroids due to its negligible oral bioavailability. ${ }^{29}$ However, the systemic effects of inhaled corticosteroids are mainly due to their resorption from the airways. The use of a spacer device may increase lung deposition and thus systemic absorption. ${ }^{3}$ There is no evidence for local metabolism of fluticasone propionate in the lung. The systemic concentration will be reduced by continuous recirculation and inactivation in the liver; the hepatic extraction ratio of fluticasone propionate is almost $100 \%{ }^{4}$ This may offer some advantages over beclomethasone dipropionate. In the lung beclomethasone dipropionate is hydrolysed to its much more active metabolite beclomethasone-17-monopropionate (17-BMP), and the majority of $17-$ BMP will reach the circulation. We did not use a spacer device in the present study. It is possible that the use of a spacer would have increased the systemic effects. However, the use of a spacer is not likely to have changed the difference between the two drugs.

With regard to the systemic effects of inhaled corticosteroids, two studies have shown significant differences in the effect on the hypothalamic-pituitary-adrenal (HPA) axis between fluticasone propionate and beclomethasone dipropionate in adult asthmatics. In the study by Leblanc et $a l^{6} 200 \mu \mathrm{g}$ fluticasone propionate daily increased serum cortisol levels compared with a (non-significant) decrease after $400 \mu \mathrm{g}$ beclomethasone dipropionate. In addition, tetracosactrin-stimulated cortisol levels were significantly higher after fluticasone propionate. In the study of Barnes and coworkers ${ }^{7}$ 
serum cortisol levels rose from 0.29 to $0.31 \mu \mathrm{mol} / 1$ after fluticasone propionate $1000 \mu \mathrm{g}$ daily, and decreased from 0.26 to $0.22 \mu \mathrm{mol} / 1$ after beclomethasone dipropionate $2000 \mu \mathrm{g}$ daily, the treatment effects being significantly different. In our study serum cortisol levels did not change significantly with relatively high doses of inhaled steroids, which corresponds with the findings by Ayres et al. ${ }^{21}$ However, most studies (including ours) only measured morning serum cortisol levels, a simple but insensitive method to detect changes in the adrenal function. This was demonstrated in the study by Nicolaizik et $a l^{30}$ who showed that morning serum cortisol levels did not change during treatment with budesonide and beclomethasone, but that 24 hour urinary secretion of free cortisol was decreased. In addition, our patients inhaled steroids without a spacer, and the duration of active treatment with each of the drugs studied was only six weeks. These factors may partly explain our inability to detect any change in adrenal function. On the other hand, we did detect a significant difference in absolute eosinophil counts in the peripheral blood, also a sensitive indicator of systemic activity. ${ }^{31}$ Absolute numbers of eosinophils decreased less with fluticasone propionate than with beclomethasone dipropionate, the treatment effect being significantly different $(p<0.01)$. In this respect fluticasone propionate showed less systemic activity than beclomethasone dipropionate.

In conclusion, fluticasone propionate $750 \mu \mathrm{g}$ daily is as effective as beclomethasone dipropionate $1500 \mu \mathrm{g}$ daily with regard to bronchial hyperresponsiveness and clinical efficacy, while the systemic activity is not increased.

Supported by a grant from Glaxo BV, The Netherlands. Medication supplied by Glaxo Research and Development, UK

1 National Heart, Lung, and Blood Institute, National Institutes of Health, Bethesda, Maryland. International consensus report on diagno

2 Guidelines on the management of asthma. Thorax 1993 48(Suppl):S1-24.

3 Barnes PJ, Pedersen S. Efficacy and safety of inhaled corticosteroids in asthma. Am Rev Respir Dis 1993;148(Suppl): S1-26.

4 Holliday SM, Faulds D, Sorkin EM. Inhaled fluticasone propionate. A review of its pharmacodynamic and pharmacokinetic properties, and therapeutic use in asthma Drugs 1994;47:318-31.

5 Dahl R, Lundbäck B, Malo J-L, Mazza JA, Nieminen MM Saarelainen $\mathrm{P}$, et al on behalf of an International Study Group. A dose-ranging study of fluticasone propionate in adult patients with moderate asthma. Chest 1993;104: 1352-8

6 Leblanc P, Mink S, Keitinen T, Saarelainen PA, Ringda $\mathrm{N}$, Payne SL. A comparison of fluticasone propionate $200 \mu \mathrm{g} /$ day with beclomethasone dipropionate $400 \mu \mathrm{g} / \mathrm{day}$ in adult asthma. Allergy 1994;49:380-5.

7 Barnes NC, Marone G, Di Maria GU, Visser S, Utama I, Payne SL. A comparison of fluticasone propionate, $1 \mathrm{mg}$ daily, with beclomethasone dipropionate, $2 \mathrm{mg}$ daily, in the treatment of severe asthma. Eur Respir 7 1993;6: 877-84.

8 Langdon CG, Thompson J, UK study group. A multicentre study to compare the efficacy and safety of inhaled flu- ticasone propionate and budesonide via metered-dose inhalers in adults with mild-to-moderate asthma. $\mathrm{Br} f$ Clin Res 1994;5:73-84.

9 Langdon CG, Capsey LJ, UK study group. Fluticasone propionate and budesonide in adult asthmatics: a comparison using dry-powder devices. Br $\mathcal{F}$ Clin Res 1994;5: 84-99.

10 Pauwels R, Joos G, Van der Straeten M. Bronchial hyperresponsiveness is not bronchial hyperresponsiveness is not asthma. Clin Allergy 1988;18:317-21.

11 Anderson SD, Smith CM. Osmotic challenges in the assessment of bronchial hyperresponsiveness. Am Rev Respir Dis 1991;143(Suppl):S43-6.

12 American Thoracic Society. Standards for the diagnosis and care of patients with chronic obstructive pulmonary disease

13 Oosterhoff Y, Koëter GH, de Monchy JGR, Postma DS. Circadian variation in airway responsiveness to metaCircadian variation in airway responsiveness to metacholine, propranolol, and AMP in atopic
jects. Am Rev Respir Dis 1993;147:512-7.

14 Cockcroft DW, Killian DN, Mellon JA, Hargreave FE. Bronchial reactivity to inhaled histamine; a method and clinical survey. Clin Allergy 1977;7:235-43.

15 Groot CAR, Lammers JW, Festen J, van Herwaarden CLA. Refractoriness for ultrasonically nebulized distilled water and histamine after histamine challenge. $\mathcal{f}$ Appl Physiol 1991;70:1011-5.

16 Stark RD. Dyspnoea: assessment and pharmacological manipulation. Eur Respir f 1988;1:280-7.

17 Jones B, Kenward MG. Design and analysis of cross-over trials. London: Chapman and Hall, 1989:16-88.

18 Bland JM, Altman DG. Statistical methods for assessing agreement between two methods of clinical measurement. Lancet 1986;ii:307-10.

19 Higgins BG, Britton JR, Chinn S, Jones TD, Jenkinson D, Burney PGJ, et al. The distribution of peak expiratory flow variability in a population sample. Am Rev Respir Dis 1989;140:1368-72.

20 Meulenberg PMM, Ross HA, Swinkels LMJW, Benraad TJ. The effect of oral contraceptives on plasma-free and salivary cortisol and cortisone. Clin Chim Acta 1987;165: 379-85.

21 Ayres JG, Bateman ED, Lundbäck B, Harris TAJ, on behalf of an International Study Group. High dose fluticasone propionate, $1 \mathrm{mg}$ daily, versus fluticasone propionate, $2 \mathrm{mg}$ propionate, $1 \mathrm{mg}$ daily, versus fluticasone propionate, $2 \mathrm{mg}$ daily or budesonide, $1.6 \mathrm{mg}$ daily, in patients
severe asthma. Eur Respir $\mathcal{f} 1995 ; 8: 579-86$.

22 Fabbri L, Burge PS, Croonenborgh L, Warlies F, Weeke B, Ciaccia A, on behalf of an International Study Group. Comparison of fluticasone propionate with beclomethasone dipropionate in moderate to severe asthma treated for one year. Thorax 1993;48:817-23.

23 O'Shaughnessy KM, Wellings R, Gillies B, Fuller RW. Differential effects of fluticasone propionate on allergenevoked bronchoconstriction and increased urinary leukotriene E4 excretion. Am Rev Respir Dis 1993;147:1472-6.

24 Vathenen AS, Knox AJ, Wisniewski A, Tattersfield AE. Time course of change in bronchial reactivity with an inhaled corticosteroid in asthma. Am Rev Respir Dis 1991; 143:1317-21.

25 Groot CAR, Lammers JW, Molema J, Festen J, van Herwaarden CLA. Effect of inhaled beclomethasone and nedocromil sodium on bronchial hyperresponsand nedocromil sodium on bronchial hyperresponsiveness to hi

26 Mattoli S, Forensi A, Corbo GM, Valente S, Patalano F, Ciappi G. Increase in bronchial responsiveness to metacholine and late asthmatic response after inhalation of ultrasonically nebulized distilled water. Chest 1986;90: 726-32.

27 O'Conner BJ, Ridge SM, Barnes PJ, Fuller RW. Greater effect of inhaled budesonide on adenosine 5'-monophosphate-induced than on sodium-metabisulfite-induced phosphate-induced than on sodium-metabisulfite-induced 146:560-4.

28 Juniper EF, Kline PA, Vanzieleghem MA, Hargreave FE. Reduction of budesonide after a year of increased use: a Reduction of budesonide after a year of increased use: a
randomized controlled trial to evaluate whether imrandomized controlled trial to evaluate whether improvements in airway responsiveness and clinical asthma
are maintained. $\mathcal{F}$ Allergy Clin Immunol 1991;87:483-91.

29 Harding SM. The human pharmacology of fluticasone propionate. Respir Med 1990;84(Suppl A):25-9.

30 Nicolaizik WH, Marchant JL, Preece MA, Warner JO. Endocrine and lung function in asthmatic children on inhaled corticosteroids. Am $\mathcal{F}$ Respir Crit Care Med 1994; 150:624-8.

31 Toogood JH, Baskerville JC, Jennings B, Lefcoe NM, Johansson SÅ. Influence of dosing frequency and schedule on the response of chronic asthmatics to the aerosol steroid, budesonide. $\mathcal{F}$ Allergy Clin Immunol 1982;70:28898 . 